Article

\title{
Web Accessibility for People with Disabilities in the European Union: Paving the Road to Social Inclusion
}

\author{
Delia Ferri $^{1, *}$ and Silvia Favalli ${ }^{2}$ (D) \\ 1 Department of Law, Maynooth University, Maynooth W23 TW77, Ireland \\ 2 Department of Political and Social Sciences, University of Pavia, Pavia 27100, Italy; silvia.favalli01@ateneopv.it \\ * Correspondence: delia.ferri@mu.ie; Tel.: +353-01-474-7210
}

Received: 30 April 2018; Accepted: 8 June 2018; Published: 12 June 2018

\begin{abstract}
Despite the drawbacks and the challenges highlighted by several scholars, Information and Communication Technology (ICT), in particular the World Wide Web, has the potential to foster social inclusion of people with disabilities. The UN Convention on the Rights of Persons with Disabilities (UNCRPD), which entered into force in 2008, has illuminated the role technology can play as a tool to promote the human rights of people with disabilities, and their participation and inclusion in society. The UNCRPD has also conceptualized ICT accessibility as a precondition for the enjoyment of rights, prompting a series of reforms in domestic legal frameworks globally and in the European Union (EU). Against this background, this article aims to address the role played by the EU in fostering "digital inclusion", and critically evaluates relevant EU policies and legal rules, locating them within the broader realm of the implementation of the UNCRPD. It pays particular attention to Directive 2016/2102 on the accessibility of the websites and mobile applications of public sector bodies, as well as on the proposal for a European Accessibility Act (EAA). It attempts to show that, while the EU has thus far played an extremely important role in fostering web accessibility, many remaining obstacles must be eradicated to fully ensure access to the web to people with disabilities. This article adopts a doctrinal legal research methodology and is primarily concerned with the analysis of relevant legal rules and related scholarship. In addition, it is informed by a socially-oriented understanding of disability and builds upon the multifaceted and multidisciplinary literature on disability and technology.
\end{abstract}

Keywords: Web accessibility; UN Convention on the Rights of Persons with Disabilities; European Union; European Accessibility Act; Web Accessibility Directive; social inclusion

\section{Introduction}

Several disability law and policy scholars observe that, in recent decades, technology has enabled more people with disabilities than ever before to actively participate in society [1-3]. Watson and Woods [4] argue that technological advances and, in particular, Information and Communication Technology (ICT), ${ }^{1}$ have played an important role in fostering participation among people with disabilities in society and have further enhanced disability activism and the disability movement [5].

1 In this article we refer to a general definition of Information and Communication Technology (ICT) such as those included in the European Standard-EN 301549 (see then Section 4). ICT is «technology, equipment, or interconnected system or subsystem of equipment for which the principal function is the creation, conversion, duplication, automatic acquisition, storage, analysis, evaluation, manipulation, management, movement, control, display, switching, interchange, transmission, reception, or broadcast of data or information». Examples of ICT include electronic content, telecommunications products, computers and ancillary equipment, software, information kiosks and transaction machines, videos, IT services, 
Areheart and Stein [6] affirm that, when ICT is available to people with disabilities, they can speak, gather, organize, and build communities in virtual spaces, and this creates "an unprecedented opportunity to increase social participation for people with disabilities". In a similar vein, the study "Stairway to Heaven?" [7] claimed that ICT "increases opportunities for participation in the workplace for persons with disabilities". According to Clayton and McDonald [8], the use of digital technologies "is destined to enable new ways of engagement with local services, education and the workforce, which would have been restricted previously due to the nature of certain impairments". They also affirm that "[t]he use of technology is not without its drawbacks and disadvantages, but for the majority who have access to ICT (in particular, computers and the Internet) there are several clear economic, educational, social and health-related advantages". Harris [9] suggests that, despite the challenges they face, "disabled people engage enthusiastically with advanced technologies and appreciate the increased independence that access to such devices can bring". Kline et al. [10] argue that "users of ICT spoke clearly about how gaining access to a computer, smart phone or the Internet greatly positively impacted on their lives".

The acknowledgement that ICT can foster participation and inclusion of people with disabilities in society goes hand in hand with the recognition that digital technologies may also create a system of exclusion. Goggin and Newell [11] affirm that, in many instances, ICT have further excluded people with disabilities and acted as barriers to participation rather than as facilitators. There are also multiple existing studies that document a digital divide between people with disabilities and people without disabilities, and which discuss the phenomenon of "digital exclusion" [12-15]. For example, Smith Ekstrand [16] recently reported that a US study characterized the digital divide between people with disabilities and those without as "large". At times, the barriers faced by people with disabilities are the result of inaccessible hardware, or lack of connections. However, these barriers often arise from the inaccessibility of online websites or mobile applications (apps). It has been shown that the tendency of Web designers to add increasingly complex components to their Web pages for the purposes of creating aesthetically appealing and interactive websites also creates added barriers for people with disabilities [17]. In this respect, Myhill and Blank [18] affirm that the potential for inclusion is strongly dependent upon making the web itself more accessible. Along these lines, other authors have argued strongly in favor of ensuring that the web is fully accessible, as this is essential if the social inclusion of people with disabilities is to be promoted and enhanced [19-23]. The European Commission has also acknowledged that accessibility has become increasingly necessary due to the rapid growth of online information and interactive services provided on the web, and that the "lack or absence of accessibility contributes to the exclusion or partial exclusion of many people from society".

A major impetus towards improving web accessibility stems from the entry into force of the UN Convention on the Rights of Persons with Disabilities (UNCRPD) [24]. The UNCRPD is currently the most relevant piece of international law in the field of disability and represents the benchmark against which domestic legislation is to be assessed. In underlining the importance of accessibility, it has also highlighted the role that accessible technology might play in the promotion and protection of the rights of people with disabilities and inter alia imposes on its States Parties a clear obligation to guarantee people with disabilities access to ICT. The importance of web accessibility has further been emphasized by the Committee on the Rights of Persons with Disabilities (UNCRPD Committee), which was established by the UNCRPD. In $F v$ Austria [25] (p. 12), the Committee affirmed that

"The importance of information and communications technology lies in its ability to open up a wide range of services, transform existing services and create greater demand for access to information and knowledge, particularly in underserved and excluded populations, such as persons with disabilities". 
In Europe, the European Union (EU) has undertaken a series of actions, both at a policy and a legislative level, to make European websites accessible to people with disabilities. Some of these actions are quite clearly intended to implement the Convention, which the EU concluded in 2009 [26,27].

Against this background, this article discusses web accessibility, i.e., the principles and techniques to be observed when designing, constructing, maintaining, and updating websites and mobile applications to make them more accessible to users, and in particular people with disabilities. It focuses on the EU actions to enhance web accessibility, placing them in a human rights context, i.e., that of the implementation of the UNCRPD. This article does not engage in a thorough legal analysis. Rather, it aims to highlight current trends in the EU actions on web accessibility, and to briefly discuss their strengths and weaknesses. The overall aim is to critically evaluate the role played by the EU in fostering "digital inclusion" for European Union citizens with disabilities. It adopts a doctrinal legal methodology, to provide a systematic exposition of the relevant legal rules on accessibility, but also "analyses the relationship between rules, explains areas of difficulty and, perhaps, predicts future developments" [28]. The analysis is based on primary legal sources, both EU hard and soft law, and on legal scholarship. It is also informed by disability studies and by the social model of disability, i.e., the understanding that disability is a social construct and derives from the interaction between an individual's impairment and external barriers. Consequently, it builds on the multifaceted literature that investigates environmental and social barriers, and disabling policy in a broad sense [29,30]. It finally builds upon the wide literature on disability and technology that is currently available [31], considering IT studies on web accessibility.

Following on from these introductory remarks, Section 2 briefly traces the background and the scope of the analysis, defining and discussing web accessibility. Section 3 provides an examination of the relevant UNCRPD provisions referring to web accessibility. This section aims to place web accessibility within a human rights context. Section 4 focuses on the relevant EU policy framework, analyzing the European Disability Strategy 2010-2020 (EDS) [32] (Section 4.1) and the Digital Agenda for Europe (DAE) [33] (Section 4.2), and their role in enhancing web accessibility in Europe. This section does not endeavor to undertake a detailed analysis. Rather, it aims to detect the core elements of these policy documents. Section 5 succinctly presents the main features of the Directive (EU) 2016/2102 on the accessibility of the websites and mobile applications of public sector bodies (Web Accessibility Directive) [34] (Sections 5.1 and 5.2) and the European Accessibility Act proposal (which remains within the approval process) [35] (Section 5.2). Section 6 concludes with some general remarks regarding how the EU can meet the challenges of digital inclusion and fully implement the spirit of the UNCRPD on this issue.

\section{Web Accessibility in Europe: A "Factual Background"}

This article focuses on how the EU can promote web accessibility, on the premise that this is vital in fostering the "digital inclusion" of people with disabilities. At the outset of this analysis, it is essential to define web accessibility and trace the scope of the subsequent legal analysis by providing data on web accessibility in Europe.

\subsection{Web Accessibility and Standards}

People with disabilities are more likely than other groups to encounter barriers when attempt to access the Internet. The purpose of Web accessibility is to eradicate these barriers and enable all users to have equal access to information and functionalities on the web. It means that people can perceive, understand, navigate, and interact with and contribute to the web, regardless their abilities or disabilities. In other words, it is the practice of making websites accessible to people who require more than just traditional Web browsers to access the Internet [36]. Web accessibility benefits a wide range of users regardless the type of disabilities (physical, sensory, intellectual, and cognitive), including older people or people with temporary impairments [37]. 
The degree to which something is considered accessible is generally based upon the relevant guidelines and standards set by standardization organizations [38]. The latter are, in general, private bodies, which include various stakeholders, and which develop, issue and revise standards, i.e., technical or quality requirements which specify the technical or normative requirements of goods, services and production processes. ${ }^{2}$ Standards are generally voluntary, and their regulatory capacity of standards "does not rest on the authority of a sovereign state but on their perceived legitimacy and relevance or, in some cases, on the pressure exerted by third parties" [39]. However, they can be implemented or incorporated within domestic legal frameworks by legislative provisions.

As already noted by Easton [40], the main self-regulatory body in relation to access to the Internet is the World Wide Web Consortium (W3C), an international consortium where member organizations, full-time staff, and the public work in tandem to pursue its objectives. There are several web accessibility organizations, different stakeholders, and research centers involved, as well as private companies and bug-tech multinationals such as Adobe, IBM, Google, Microsoft. Beginning in 1994, the W3C "began creating a new foundational language for the future of the Web" to counteract the unregulated, complex, and cumbersome growth of the Web [41]. It also created various working groups to develop web standards, guidelines, and supporting materials within the realm of the Web Accessibility Initiative (WAI) [42]. The Briefing Package for the creation of the WAI stated that

"Worldwide, there are more than 750 million people with disabilities. A significant percentage of that population is affected by the emergence of the Web, directly or indirectly. For those without disabilities, the web is a new technology that can help unify geographically dispersed groups. However, these barriers put the web in danger of disenfranchising people with disabilities in this emerging infrastructure".

The Accessibility Guidelines Working Group (formerly WCAG Working Group), which is part of the WAI, developed WCAG technical documents. Kennedy et al. [43] affirmed that "[g]uidance developed by the WAI plays a crucial role in promoting accessible practices". The series of guidelines (i.e., Authoring Tools Accessibility Guidelines (ATAG) for producers of web design software; User Agent Accessibility Guidelines (UAAG) for the manufacturers of Web browsers and the assistive technologies that people with disabilities use to access the Web, such as screen readers; and Web Content Accessibility Guidelines for Web designers and other people involved in the production of Web sites) provide an invaluable tool in ensuring equal access to people with disabilities.

In 1999, the W3C established the first accessibility standard for the Web, WCAG 1.0. Almost ten years later, in December 2008, the WAI revised the WCAG guidelines and published an updated version (i.e., WCAG 2.0 [44]), which are currently in use. The WCAG 2.0 guidelines are accepted as the primary standard by which accessibility should be measured. They are composed of 12 separate guidelines, organized under 4 principles: perceivability (meaning that information and user interface components must be presentable to users in ways they can perceive), operability (meaning that user interface components and navigation must be operable), understandability (meaning that information and the operation of the user interface must be understandable), and robustness (meaning that content must be robust enough to be interpreted reliably by a wide variety of user agents, including assistive technologies). For each guideline, there are measurable criteria for success, which are at three levels: A, AA, and AAA. Level A signifies a fundamental access standard and Level AAA denotes a maximum level of accessibility. However, it is not possible to satisfy all Level AAA Success Criteria for some content. In this vein, it is not recommended that Level AAA conformance be required as a general

2 According to the International Standardization Organization, a standard is a «document, established by consensus, and approved by a recognized body, that provides for common and repeated use, rules, guidelines, or characteristics for activities or their results, aimed at the achievement of the optimum degree of order in a given context» (International Organization for Standardization (2001). Rules for structure and drafting of international standards, 4th edition. Geneva: ISO/IEC, p. 9). 
policy for entire sites [45]. Duchateau et al. highlight that as a standard, the WCAG 2.0 proposes objectives and provides tools by which to achieve them. However, they do not provide a step-by-step methodology and grant a degree of discretion in terms of how these objectives are to be realized [46].

So far, the WCAG 2.0 guidelines have been widely incorporated or adopted into policy and legislative frameworks. At the European level, in 2014, a new standard was elaborated by the European Standardization organizations, with a large input from the European Telecommunications Standards Institute (ETSI), the Human Factors Technical Committee (HF), and the eAccessibility Joint Working Group (JWG) of the three European Standardization Organizations (the European Committee for Standardization (CEN), the European Committee for Electrotechnical Standardization (CENELEC) and ETSI) ${ }^{3}$ This standard specifies the functional accessibility requirements applicable to ICT products and services, and refers to the WCAG 2.0, which remain the main point of reference in relation to ICT accessibility.

However, on the one hand, Brown and Hollier [47] claim that the implementation of the WCAG 2.0 guidelines has thus far been quite slow. This may be attributed to a series of different factors, which include the complexity of the guidelines themselves, the lack of accessibility awareness when designing and implementing websites, the latter of which has been observed primarily (but not exclusively) in developing countries [48]. Among the challenges to the successful implementation of the WCAG 2.0, the scarcity of professionals who are familiar with accessibility evaluation tools and the current dearth of appropriate structured accessibility manuals for web developers. On the other hand, although the WCAG 2.0 are currently considered the most advanced standard, they have not been without criticism. In 2006, Clark [49] (p. 3) claimed that the WCAG 2.0 guidelines were "written and rewritten and rewritten to apply to everything" and "it lost the ability to apply to the real things real developers work on every day". He also claimed that the guidelines were hard to interpret and to apply in a practical sense. Other scholars affirm that the WCAG 2.0 guidelines have not increased the coverage of user problems, as one would have expected, compared to the WCAG 1.0 [50]. Power et al. have shown that blind users encounter several barriers in accessing the web, even when the website is compliant to the WCAG 2.0. Other scholars suggest that the WCAG 2.0 do not provide full accessibility to people with intellectual disability. Kennedy et al. [43] suggest that users with severe intellectual disabilities require far greater levels of technical and authoring adaptations than those provided for in the WCAG guidance, and that more research is needed into this issue. These challenges contribute to the persistence of barriers in web accessibility.

\subsection{Web Accessibility in Europe}

People with disabilities represent a large proportion of the EU population that still encounters barriers in relation to their full participation in society. In 2012, the Flash Eurobarometer survey on accessibility [51] found (quite unsurprisingly) that according to $93 \%$ of the respondents, "barriers to accessibility make it more difficult for people with a disability to attend schools, to have a job, to vote and/or to freely move around and go on holiday". It also highlighted that 7 in 10 Europeans believe that more accessible goods and services would improve the lives of people with disabilities. The survey further suggested that $86 \%$ of Europeans agree that having similar accessibility solutions across Europe would enable people with disabilities to travel, study and work in another EU Member State, inevitably supporting the case for an EU-wide legislation on the issue. In 2015, the Commission launched a public consultation to solicit the views of a broad range of stakeholders on the impact of the European Disability Strategy 2010-2020, which will be outlined in greater detail in Section 4 [52]. The results of this consultation, divulged in a progress report which was released on 2 February

3 The members of CEN and CENELEC are the National Standardization Bodies and National Electrotechnical Committees of several European countries. European Standards (ENs) adopted by CEN and CENELEC, are accepted and recognized in all these countries. European Standards (ENs) are developed through a process of collaboration among experts nominated by business and industry, research institutes, consumer and environmental organizations, trade unions and other stakeholders. 
2017, highlighted that people with disabilities face a series of challenges in terms of accessibility, discrimination, participation in employment and their intra-EU mobility.

When it comes to web accessibility, recent studies confirm that disability status is a significant factor in differentiating Internet access in European countries [53,54]. The Eurobarometer report on discrimination in the EU, released in 2012 [55], indicates that there is gap in Internet access of more than 20 percentage points between people with disabilities and non-disabled people. In Europe, there are few up-to-date comprehensive statistics on web accessibility. However, the available data illustrates that web accessibility remains persistently low. A 2004 UK study on the accessibility of public websites affirmed that less than 20 per cent of websites meets the most basic accessibility standards across the full spectrum of disabilities including hearing, motor, and sight impairment [56,57]. More recent studies tend to demonstrate that, while accessibility has increased, the majority of e-government websites among several Member States remain inaccessible to people with disabilities [58-61]. EU Member States have put in place a range of national web accessibility policies [62,63], but there are still significant discrepancies in terms of the practical supports and tools provided across the EU [64]. Several public service websites do not comply with the WCAG 2.0 AA requirements. For example, research conducted on Italian public health institutions' websites showed that their level of accessibility is extremely modest $[65,66]$. While countries with stronger disability laws tend to operate more accessible e-government sites, disability policy alone does not guarantee absolute adherence to accessibility standards [58]. Even the EU websites were not considered to be fully accessible. In this respect, in November 2017, the European Parliament, while highlighting that the EU institutions' websites do not comply with level AAA accessibility standards, "urge[d] the EU institutions to make accessible the functionality, content, documents, videos and web services of their external and internal websites, including public consultations, and public reports on conformity and compliance with web accessibility guidelines, recommendations and obligations" [67].

Accessibility levels of private websites are even lower, and this has also inevitable negative economic repercussions [68,69]. Interestingly, a 2016 survey conducted in the UK (the Click-Away Pound Survey 2016 [70]) revealed that 73\% of participants with access needs experienced barriers on more than a quarter of websites they visit for the first time; a third experience such barriers on more than half of websites. The survey also reveals that $71 \%$ of disabled customers with access needs will leave websites that they find difficult to use. Recently, Lorca et al. [71] released a research on the accessibility of Spanish banking websites. They found that firm size is negatively related to the level of web accessibility. Since web accessibility is "becoming a source of competitive advantage for businesses", small banks with limited resources are more inclined to implement it. However, awareness of the negative market repercussions of inaccessible websites seems increasing among market operators.

\section{Web Accessibility as a Human Right in the UNCRPD}

Web accessibility is not only a tool for enhancing the participation and inclusion of people with disabilities in society, as highlighted in the introduction to this article, following the entry into force of the UNCRPD, it has also been brought within the realm of human rights for people with disabilities. The Preamble to the Convention, at para (v), explicitly recognizes "the importance of accessibility to the physical, social, economic and cultural environment, to health and education and to information and communication, in enabling people with disabilities to fully enjoy all human rights and fundamental freedoms". "Accessibility" is also mentioned as one of the general principles of the Convention in Article 3 UNCRPD. This is further developed in Article 9 UNCRPD and in other substantive provisions. Article 9(1) demands the adoption of all measures necessary to ensure accessibility on a progressive basis. In the recently published General Comment No. 6 on "Article 5: Equality and non-discrimination", adopted on 9 March 2018, the UNCRPD Committee affirmed, consistently to what already established in the General Comment No. 2 on accessibility [72], that 
"Accessibility is a precondition and a means to achieve de facto equality for all persons with disabilities. For persons with disabilities to effectively participate in the community, States parties must address accessibility of the built environment, public transport, as well as information and communication services (emphasis added), which must be available and usable for all persons with disabilities on an equal basis with others".

It also confirmed that accessibility duties relate to groups may be implemented gradually but must be done unconditionally.

Article 9(2)(a) obliges States Parties inter alia to develop accessibility standards. In doing so, this provision leaves the door open for Parties to delegate the writing of technical standards to non-state authorities. The UNCRPD implicitly acknowledges that technical specifications and accessibility standards have primarily been established in booklets, studies prepared by "think tanks", or in "private" rules elaborated by standardization bodies. The UNCRPD Committee, in its General Comment No. 2 [72], urged States Parties to give effect to the mandatory application of accessibility standards and to ensure that those standards are "in accordance with the standards of other States parties in order to ensure interoperability with regard to free movement within the framework of liberty of movement and nationality (Article 18) of persons with disabilities". The Convention does not distinguish between public or private ownership of buildings, transport, or technologies. Article 9(2)(b)(d) makes it clear that States Parties must ensure that private entities provide for accessible services and facilities. In this respect, the UNCRPD Committee explicitly affirms that, "as long as goods, products and services are open or provided to the public, they must be accessible to all, regardless of whether they are owned and/or provided by a public authority or a private enterprise" [72] (p. 4). This interpretation of Article 9 is premised on the need to promote and fulfil the principles of non-discrimination and equality [73].

Most notably for this analysis, Article 9(2) paragraphs (f) and (g) concern the accessibility of information. They do not use the term web accessibility but more broadly require that State Parties "promote other appropriate forms of assistance and support to persons with disabilities to ensure their access to information" and "promote access for persons with disabilities to new information and communication technologies and systems, including the Internet", respectively. In addition, Article 9(2)(h) obliges States Parties to "promote the design, development, production and distribution of accessible information and communications technologies and systems at an early stage, so that these technologies and systems become accessible at minimum cost".

These provisions must be read in conjunction with the general obligation laid down in Article $4(1)(\mathrm{g})$ and Article 21 UNCRPD, which provide for the right to access information. The latter provision includes a non-exhaustive list of examples of measures that should be adopted to promote freedom of opinion and expression. Among other things, it requires that States Parties ensure that information, whether provided by public or private service providers and intended for the general public, is available in accessible formats (and this clearly includes accessible websites). It calls on States Parties to ensure that people with disabilities may gain access to information "in a timely manner" and "without any additional cost". As noted by Cera et al. [74], the latter condition requires that accessible information be provided without additional costs as compared to information for non-disabled users, and thus should not impose any additional costs upon people with disabilities. Article 21 also calls for the recognition, acceptance, and promotion of the use by people with disabilities of sign languages, Braille, augmentative and alternative communication, and all other accessible means, modes, and formats of communication. This implies that websites must be compatible with and support these alternative modes of communication. In this respect, the UNCRPD Committee has clearly affirmed that "accessibility in the context of communication services includes the provision of social and communication support" [75].

The UNCRPD contextualizes web accessibility as a core element of the right to independent living ensured by Article 19 UNCRPD. Furthermore, the UNCRPD Committee, in its General Comment No. 5 on living independently and being included in the community [76], clearly affirmed that "in order to 
ensure that the realization of a standardized minimum support level sufficient to allow the exercise of the right to live independently and be included in the community", State Parties must, inter alia,

"develop, implement, monitor and sanction non-compliance with legislation, plans and guidance on accessibility requirements for basic mainstream services to achieve societal equality, including participation by persons with disabilities within social media, and secure adequate competence in information and communications technologies to ensure that such technologies are developed, including on the basis of universal design, and protected".

Overall, the UNCRPD not only situates web accessibility within the realm of human rights, but also qualifies it as a necessary precondition for equality, as well as acknowledging its importance as a tool for participation and social inclusion.

\section{Web Accessibility in EU Policy: A General Overview}

The EU has developed a significant (and constantly evolving) body of disability law and policy in the last thirty years [77]. The most recent milestone in this developmental process is the ratification of the UNCRPD by the EU [78]. Within the realm of its own disability policy, which currently revolves around the European Disability Strategy 2010-2020, web accessibility has acquired a high level of importance, and can also be seen in the EU2020 strategy objectives [79]. Within the latter strategy, whose overall goals are to increase employment rates and to make the EU a smart and sustainable economy, the EU has developed a Digital Agenda (DAE) [33], which complements the Digital Single Market Strategy [80] (p. 3). In this context, along the lines already traced by the previous eEurope Action Plans 2002 and 2005, accessibility standards for public websites and digital inclusion have gained a seminal importance [29].

The remainder of this section succinctly presents both the EDS and the DAE, to highlight their strengths and weaknesses and their role when it comes to fostering web accessibility.

\subsection{The European Disability Strategy}

The European Disability Strategy 2010-2020 (the EDS) [32] proposes a wide-ranging and mainstream policy action, "constitut[ing] a comprehensive multiannual framework for implementing the United Nations Convention on the Rights of Persons with Disabilities" [81]. It was adopted by the Commission at the end of 2010, further to a resolution of the Council [82], which had invited the Commission "to prepare, in cooperation with the Member States, persons with disabilities and their representative organizations and other relevant stakeholders, a new European Disability Strategy building on the values enshrined in the European Treaties, the Europe 2020 strategy and the UN Convention" (paragraph 24). The EDS lays down the current disability policy agenda and has the "overall aim" of "empower[ing] people with disabilities so that they can enjoy their full rights and benefit fully from participating in society and in the European economy". The Strategy explicitly refers to the UNCRPD and aims to implement its obligations. It sets out eight interconnected key areas of action: accessibility, participation, equality, employment, education and training, social protection, health, and external action. It identifies EU-level actions that, alongside national measures, are designed to achieve these goals and "ensure effective implementation of the UN Convention across the EU" [83].

The EDS, in the same vein of the UNCRPD, recognizes that accessibility is a "precondition for participation in society and in the economy". In the Strategy, accessibility is defined consistently with the Convention as "meaning that people with disabilities have access, on an equal basis with others, to the physical environment, transportation, information and communications technologies and systems (ICT), and other facilities and services" [32] (p. 5).

The EDS indicates that the Commission will use legislative and other instruments, such as standardization, to optimize the accessibility of the built environment, transport, and ICT. It will also foster an EU-wide market for assistive technology. The main objective of the EDS in this field is to 
"prevent, identify and eliminate obstacles and barriers to accessibility" and ICT is one of the key areas of action. One of the first actions taken by the Commission was to launch a cost-benefit analysis and data collection study on the accessibility of goods and services in the areas of ICT, built environment and transport addressing the functioning of the internal market, in preparation for the possible development of a European Accessibility Act (EAA). This was conducted to lay the groundwork for the future drafting of a legislative proposal for the EAA. The Commission also identified as core actions the development of accessibility standards (European Standard EN 301 549) for ICT and their use in public procurement in the context of Mandate 376- "Accessibility requirements suitable for public procurement of ICT products and services in Europe" [84]. This mandate predates the EDS, as it was released in 2005. This mandate was, in reality, meant to complement the Public Procurement Directive's requirement that technical specifications be established in contracting documents, and was subsequently revamped with the EDS. The objective of the mandate was to identify a set of functional European accessibility requirements and to provide an electronic toolkit so that public contracting authorities could use the requirements in their calls for tender. After the preparation of "an inventory of European and international functional accessibility requirements and of gaps in existing requirements" [85], a user-friendly list of functional accessibility requirements for ICT products and services was developed. This voluntary standard was adopted in 2014, and despite containing no legally binding obligations for public procuring bodies or other public or private people or entities, clarifies the functional accessibility requirements applicable to ICT products and services. The standard is "the basis for an accessible ICT procurement toolkit" and aims to be a useful tool for public procurement officers to identify the requirements for their purchases, and for manufacturers to employ it within their design, build and quality control procedures. According to the Commission, this standard achieved significant harmonization with the US standards. However, work is still ongoing to improve the standard and address critical issues which emerged after its adoption [67].

Despite some criticism expressed by the UNCRPD Committee in its concluding observation on the EU report [86], Hosking [83] suggests that the EDS has the potential "to bring about significant improvement to the social situation of disabled people", and, in the field of accessibility. The Commission's progress report on the EDS, released in February 2017 and discussing the main achievements in all thematic priority areas, confirms that accessibility is one of the areas in which major progress has been achieved, with legislation adopted on the accessibility of public-sector websites and the legislative proposal for a European Accessibility Act, and the adoption of the European Standard on accessible ICT (EN 301 549) [85]. However, in respect of standards, Hosking warns that "incorporating accessibility principles in the standards development process is a long-term and frustratingly slow process" and it is necessary to ensure that disabled people and organizations representing disabled people are involved with industry from the earliest design stages as new technology is being developed to ensure design for all principles are in the forefront.

\subsection{The Digital Agenda for Europe}

In the EDS, the Commission expressed its intention to include disability within the Digital Agenda for Europe (DAE), creating a link between the two policy documents which, in relation to web accessibility, must be considered complementary [33]. The DAE is one of seven flagship initiatives under the Europe 2020 Strategy. It focuses on technologies and online services and intends to "better exploit the potential of Information and Communication Technologies (ICTs) in order to foster innovation, economic growth and progress". Launched in May 2010, the Digital Agenda hopes to boost Europe's economy by delivering sustainable economic and social benefits from the creation of the digital single market, i.e., a market in which the free movement of goods, people, services, and capital is ensured and where individuals and businesses can seamlessly access and exercise online activities under conditions of fair competition, and a high level of consumer and personal data protection [80]. 
The overall objective of the DAE is to maximize the social and economic potential of ICT, and most notably the Internet. Digital technologies should foster economic and social growth, and European citizens will benefit from this growth by facilitating a better quality of life for them through, for example, better health care, safer and more efficient transport solutions, cleaner environment, new media opportunities and easier access to public services and cultural content. For these purposes, the DAE identifies seven areas for action with 100 follow up activities for both the Commission and Member States.

The Digital Agenda addresses accessibility and usability of the Internet for Europeans with disabilities. Notably, it affirms that bridging the digital divide can help members of disadvantaged social groups participate on an equal footing with others in a digital society [33] (p. 25). In this vein, the DAE recognizes the need for concerted initiatives to guarantee that new electronic content is fully available to people with disabilities, in compliance with the obligations set out in the UNCRPD. In particular, it requires that public websites and online services in the EU-that are important to enable people to take part in public life-are brought in line with the above mentioned international web accessibility standards (WCAG 2.0). For this purpose, the Commission will "systematically evaluate accessibility in revisions of legislation undertaken under the Digital Agenda, following the UN Convention on the Rights of Persons with Disabilities" [33] (p. 27). It also aims to enhance the accessibility of Europe's cultural heritage to all Europeans by advancing and using modern translation technologies [33] (p. 31), as well as the accessibility of eGovernment online services [33] (p. 32).

Ciolan [87] affirms that the DAE has the potential to foster economic growth and highlights the potential positive effects for people with disabilities. As noted by Mansell [88] (p. 204), notwithstanding the numerous references to accessibility and inclusivity, "the principal thrust [of the Digital Agenda for Europe] appears to be on ICTs as drivers of economic growth and productivity improvements, with media pluralism, for instance, following once the scaffolding for the information society is in place". In other words, the author suggests that there remains an imbalance within the DAE between commercial market considerations and disabled citizens' interests. For this reason, the DAE seems to fall short of the obligations laid down in the UNCRPD, despite explicit references to the Convention within it.

\section{The Web Accessibility Directive and New Legislative Developments: A Critical Appraisal}

In the EDS, several EU initiatives are designed to foster accessibility. Two of the most relevant legislative instruments are the Web Accessibility Directive, and the European Accessibility Act (EAA), which will be discussed below.

\subsection{The Web Accessibility Directive}

Directive (EU) 2016/2102 of the European Parliament and of the Council of 26 October 2016 on the accessibility of the websites and mobile applications of public sector bodies [34], often referred to as the "Web Accessibility Directive", entered into force on 22 December 2016. Member States have until the 23 September 2018 to incorporate the text of the Directive within their national legal systems, and at the time of the writing of this contribution, only Austria has done so through national law No. 127 of 8 November 2017 [89]. The Spanish government is currently discussing a national legislative proposal for the implementation of Directive (EU) 2016/2102 [90]. Moreover, the Commission plans to adopt implementing acts by the end of 2018 detailing the relevant technical specifications (harmonized standards). In the meantime, public sector bodies will need to comply with relevant parts of the existing European Standard EN 301549 [84]. This will ensure uniform conditions for the implementation of the relevant provisions of the Directive [91].

Originally, the Directive was designed to be part of an overall accessibility package, which also included the EAA. However, the EAA remains under discussion, and it is unclear when it will be approved. The Web Accessibility Directive aims to improve the functioning of the internal market, 
thereby enabling the websites and mobile applications of public sector bodies to be more accessible to users, and in particular to people with disabilities. It only sets out minimum requirements that must be met by public sector bodies. Member States are also "encouraged to extend the application of the Directive to private entities that offer facilities and services which are open or provided to the public" [34] (paragraph 34). The Directive also includes a provision explaining that the delivery of accessibility requirements should not impose a "disproportionate burden" upon public sector bodies (paragraph 39 and Article 5). In other words, public sector bodies shall carry out an initial impact assessment and cost-benefit analysis to decide whether complying with the accessibility requirements in the Directive imposes a "disproportionate burden". Where this burden has arguably been established, public sector bodies must outline which parts of the accessibility requirements could not be complied with and then provide accessible alternatives.

The Directive makes ample reference to standards which make websites and mobile apps more accessible. The existing European Standard EN 301549 V1.1.2 [92], adopted based on the above-mentioned Mandate 376 [84], provides harmonized standards and a common methodology to test the conformity of content on websites and mobile applications with those principles. These standards will be updated by an implementing act of the Commission by 23 December 2018 with the technical specifications (harmonized standard) that public sector bodies must meet for their websites and mobile applications. In the meantime, public sector bodies will need to comply with relevant parts of the existing European Standard EN 301549 (Article 6).

There are several weaknesses in the Directive. Firstly, the material scope of the Web Accessibility Directive is limited insofar as it only applies to websites and mobile apps operated by public sector bodies. In addition, in Article 1, paragraph 3, a small number of exemptions are enunciated which further restrict the scope of the Directive. Namely, "websites and mobile applications of public service broadcasters and their subsidiaries, and of other bodies or their subsidiaries fulfilling a public service broadcasting remit" are outside of the scope of the Directive. These websites and mobile applications would be covered by another directive (the European Accessibility Act now under discussion), which also applies to private broadcasters, to guarantee conditions of fair competition without prejudice to the public interest role performed by the audiovisual media services [34] (paragraph 23). In addition, the Web Accessibility Directive does not apply to "websites and mobile applications of NGOs that do not provide services that are essential to the public, or services that specifically address the needs of, or are meant for, persons with disabilities". Such exemption is open to interpretation, as there is no clear definition of what constitutes "services that are essential to the public" [91] (p. 10), and this could lead to divergent interpretations being adopted by the Member States. The Directive also provides for the temporary or permanent exclusion from its scope of some types of content of websites or mobile applications (Article 1, paragraph 4). Such exclusions are to be reconsidered in the context of the review of the Web Accessibility Directive, and in the light of future technological advances (paragraph 22).

Secondly, at first sight, the Directive seems to address accessibility for people with physical impairment, leaving aside people with intellectual and cognitive disabilities. This seems to emerge from the words of Vice-President of the Commission Ansip and Commissioner Oettinger, who said that: "Everyone should benefit from the opportunities offered by the Internet and fully participate in the digital society. Today's adoption is an important step in the right direction. New rules will ensure that people with disabilities-especially blind, deaf and hard of hearing persons [emphasis added]—can more easily access and use the websites and mobile applications of public services" [93]. In addition, even though the Commission itself is committed to complying with the WCAG 2.0 guidelines (compliance level AA), these fall short the needs of people with intellectual disabilities. However, features such as information in sign language and easy-to-read formats-essential for people with intellectual disabilities_-go beyond the WCAG. For this reason, on 12 July 2017, the European Ombudsman, Emily O'Reilly, has opened an inquiry into the accessibility of websites and online tools managed by the Commission for people with disabilities [94]. While acknowledging that the provision of such features would have an impact on resources, the Ombudsman considers that, "it would be 
reasonable to focus on areas where citizens are expected to interact with the EU administration". This would also be in compliance with the Concluding Observations regarding the EU's implementation of the Convention on the Rights of Persons with Disabilities made by the UNCRPD Committee [86], as well as with the resolution of the European Parliament from July 2016 [81]. The Commission replied that, during 2018, a plan of action on web accessibility will be prepared, which will also while consider the available budgetary and human resources [95].

In the same vein, in its report on the implementation of the UNCRPD of November 2017 [67], the European Parliament, expressed its concern that "the monitoring of some pieces of legislation, such as the Web Accessibility Directive or the Regulation on Rail Accessibility (TSI-PRM), is through self-assessment by industry and the Member States and is not conducted by an independent entity". The Parliament also recommended that the Commission improve its assessment of compliance and considers developing monitoring legislation to ensure that the rights of people with disabilities are respected.

\subsection{The EAA: Some Observations in the Making}

As mentioned above, the EDS had identified as a primary objective the creation of a legislative proposal for a "European Accessibility Act" (EAA proposal), imposing, at various levels, obligations to provide accessible goods and services. The release of an initial roadmap towards the EAA in June 2011 and a subsequent public consultation, open from the 12 December 2011 to the 29 February 2012, were followed by a period of inaction. The proposed text of the EAA [35] was eventually made public on the 2 December 2015, a day before the celebration of the International Day of Persons with Disabilities. The proposal argued in favor of a directive on the approximation of national provisions related to certain accessible products and services, based on Art. 114 TFEU. As mentioned in the proposal itself, the EAA should reduce the fragmentation of legislation on access to products and services that result from the fact Member States have adopted different accessibility requirements. The Directive, once adopted, will require Member States to ensure that the selected products and services placed in the market are accessible to people with disabilities.

The original proposal covered general purpose computer hardware and operating systems, Automatic Teller Machines (ATMs), ticketing machines, check-in machines, various types of consumer terminal, audio-visual media services, air, bus, rail and waterborne passengers transport services, banking services, e-books, and e-commerce. Products and services related to ICT, including commercial websites, are extensively covered by the proposed EAA. As noted by Easton [96], the EAA represents an opportunity to harmonize web accessibility standards in relation to commercial websites. Hence, the proposal is meant to complement and work in tandem with the Web Accessibility Directive. While the latter, as discussed above, is concerned solely with a specific set of public sector body websites, the proposal for the EAA also addresses some private sector websites. In this vein, "activities of e-commerce of public sector websites not covered by that Directive [the Web Accessibility Directive], fall under the scope of this proposal, in order to ensure that the online sale of products and services is accessible for people with disabilities and older people, irrespective of their public or private sale" [35] (recital 21). On the 26 May 2016, the European Economic and Social Committee adopted its opinion on the proposal and warmly welcomed the introduction of the EAA [97]. In particular, it recommended considering the gradual inclusion in the scope of the Directive of "websites and mobile applications made available by economic operators otherwise falling under the scope of the directive" (paragraph 5.1), and including a definition of website, "in order to avoid any possible misunderstanding related to the provision of certain functionalities on a given website through the use of third party sites" (paragraph 5.9). However, after the first reading of the Parliament, the scope was slightly reduced, and audiovisual media services were completely excluded from the reach of the EAA, although websites and mobile applications of audiovisual service providers (i.e., TV broadcasters and video on-demand services such as Netflix) are still included. The Parliament has also introduced a blanket 
exclusion of micro-enterprises from the scope of the Act, meaning that companies with less than ten employees do not have to make their products or services accessible.

As highlighted by the European Disability Forum [98], the EAA provides only functional requirements, i.e., the aspects of the product/service which must be accessible are determined. It does not specify how this is to be achieved from a technical perspective, permitting further innovation, and giving more flexibility in implementation. This is likely to be one of the most positive aspects of the EAA and aligns it with the UNCRPD. Digital advances may present as-yet-unknown further barriers to integration by people with disabilities, and it is essential that the EAA remains an instrument capable of adapting to the technical innovations.

The EAA also imposes obligations on manufacturers, representatives, importers, and distributors, and should cover all economic operators, public and private. However, there are limitations to the obligations imposed. For example, the EAA establishes that economic operators are not obliged to comply with the accessibility requirements outlined within it if these impose a disproportionate financial burden. As noted by Inclusion Europe, "this provision is problematic, as it is based on the self-assessment of the operators, instead of a formal process where economic actors may seek for being exempted from their obligation under the EAA" [99]. There are other aspects of the proposal which have also garnered criticism [98]. Some important elements, such as the provision as mandatory of the use of accessibility requirements for public authorities when using EU funds or in public procurements procedures have been excluded, as well as the previously mentioned exclusion of micro-enterprises from the personal scope of the proposal. In addition, the proposal does not consider the specific accessibility needs of people with intellectual and cognitive disabilities. In this vein, Inclusion Europe suggests the addition of adequate enforcement provisions within the proposed directive, i.e., making specific mention of easy-to-read and pictograms as tools to comply with the requirement of understandability for products and services covered by the EAA, and providing people with disabilities the possibility to seek assistance from the staff of the service provider.

Nonetheless, at the time of the writing of this piece, there is still some space for other amendments during the ongoing legislative process to be adopted. This must be balanced against the need to avoid a deadlock situation, and to ensure the swift adoption of the Directive. On the 15 September 2017, the European Parliament adopted its first reading position on the EAA [100], while on the 7 December 2017 the Council agreed on a position (general approach) [101]. Moreover, in the 2018 Joint Declaration [102], the Commission, the Council and the European Parliament have committed to agreeing this on several priority proposals among which the "Accessibility requirements for products and services". The Joint Declaration makes it likely that the EAA will be adopted, but it remains to be seen when. Most importantly the overall shape and content of the EAA remains in flux, and it is not possible to fully assess whether the drawbacks and the weaknesses of the current EAA text will be improved.

\section{Conclusions}

The Web has become a mainstream communications medium and an integral part of people's lives. However, the growing use of the Internet for information, education, social contact and, increasingly, the provision of goods and services, has created a "digital divide" between disabled people and other users. This divide was observed globally, and is not static, but linked to the evolving nature of ICT. Web accessibility has become essential to bridge such a divide and to facilitate and ultimately improve the inclusion of people with disabilities. In fact, as noted by Areheart and Stein [6], "[M]uch as physical access ... was critical for social interaction and consequent equality of opportunity, virtual access is now critical for integrating people with disabilities and breaking down stereotypes."

Although legal rules cannot by themselves ensure web accessibility they can trigger compliance with standards. Several lawsuits, particularly in the US and in Canada, on the issue of website accessibility show that accessibility legislation (and the possibility to enforce it) is key to boost web accessibility [103]. In Europe, despite the relatively well embedded nature of anti-discrimination 
laws, statistics and studies show that the situation for people with disabilities remains challenging in terms of access to new technologies, and in particular websites and other online services. In this context, the role of the EU accessibility legislation in promoting web accessibility is essential. The Web accessibility Directive and the EEA in combination, despite some drawbacks, have the potential to significantly boost accessibility of public and private websites. However, as noted by Mansell [88], the risk of an imbalance between commercial market considerations and disabled citizens' interests features high. In this vein, it is crucial that the future EU digital policy action, and the forthcoming EAA will be underpinned by the principles of the UNCRPD, to effectively paving the road to the social inclusion of European with disabilities in the EU digital society.

Author Contributions: This article is the product of a joint reflection. However, Sections 2, 3, 4.1 and 5.2 have been written by Delia Ferri, Sections 4.2 and 5.1 have been written by Silvia Favalli, while Sections 1 and 6 have been written jointly.

Funding: This research received no external funding.

Acknowledgments: The research of Silvia Favalli was conducted under the project Blue Sky Research 2017, financed by the University of Pavia.

Conflicts of Interest: The authors declare no conflict of interest.

\section{References}

1. Foley, A.; Ferri, B.A. Technology for people, not disabilities: Ensuring access and inclusion. J. Res. Spec. Educ. Needs 2012, 12, 192-200. [CrossRef]

2. Blanck, P.D.; Braddock, D.L. eQuality: The Struggle for Web Accessibility by Persons with Cognitive Disabilities; Cambridge University Press: New York, NY, USA, 2016; ISBN 9781107051805.

3. Ferri, D.; Giannoumis, G.A.; O'Sullivan, C.E. Fostering accessible technology and sculpting an inclusive market through regulation. Int. Rev. Law Comput. Technol. 2015, 29, 81-87. [CrossRef]

4. Watson, N.; Woods, B. The origins and early developments of special/adaptive wheelchair seating. Soc. Hist. Med. 2005, 18, 459-474. [CrossRef]

5. Lewthwaite, S. Web accessibility standards and disability: Developing critical perspectives on accessibility. Disabil. Rehabilit. 2014, 36, 1375-1383. [CrossRef] [PubMed]

6. Areheart, B.A.; Stein, M.A. Integrating the Internet. University of Tennessee Legal Studies Research Paper No. 231. Available online: https:/ / ssrn.com/abstract=2420510 (accessed on 30 April 2018).

7. Fossestol, K. Stairway to Heaven? ICT POLICY, Disability and Employment in Denmark, The Netherlands, UK and Norway. 2007. Available online: http://www.hioa.no/Om-HiOA/Senter-for-velferds-ogarbeidslivsforskning/AFI/Publikasjoner-AFI/Stairway-to-Heaven (accessed on 30 April 2018).

8. Macdonald, S.J.; Clayton, J. Back to the future, disability and the digital divide. Disabil. Soc. 2012, $28,702-718$. [CrossRef]

9. Harris, J. The use, role and application of advanced technology in the lives of disabled people in the UK. Disabil. Soc. 2010, 25, 427-439. [CrossRef]

10. Kline, J.; Ferri, D. Enabling people with disabilities through effective accessible technology policies. In The Changing Disability Policy System: Active Citizenship and Disability in Europe; Halvorsen, R., Hvinden, B., Bickenbach, J., Ferri, D., Guillén Rodriguez, A., Eds.; Routledge: London, UK, 2017; pp. 127-143. ISBN 9781317227502.

11. Goggin, G.; Newell, C. Digital Disability: The Social Construction of Disability in New Media; Rowman \& Littlefield: Lanham, MD, USA, 2003.

12. Watling, S. Digital exclusion: Coming out from behind closed doors. Disabil. Soc. 2011, 4, 491-495. [CrossRef]

13. United Nations E-Government Survey. Chapter 5, Bridging the Digital Divide by Reaching Out to Vulnerable Populations. 2012. Available online: https://publicadministration.un.org/egovkb/Portals/egovkb/ Documents / un/2012-Survey/Chapter-5-Bridging-the-digital-divide-by-reaching-out-to-vulnerablepopulations.pdf (accessed on 30 April 2018).

14. Goggin, G. Disability and Digital Inequalities: Rethinking Digital Divides with Disability Theory. In Theorizing Digital Divides; Muschert, G.W., Ragnedda, M., Eds.; Routledge: New York, NY, USA, 2017; pp. 69-80. ISBN 9781138210400. 
15. Easton, C. An examination of the Internet's development as a disabling environment in the context of the social model of disability and anti-discrimination legislation in the UK and USA. Univers. Access Inf. Soc. 2013, 12, 105-114. [CrossRef]

16. Smith Ekstrand, V. Democratic Governance, Self-Fulfillment and Disability: Web Accessibility under the Americans with Disabilities Act and the First Amendment. Commun. Law Policy 2017, 22, 427-457. [CrossRef]

17. Hackett, S.; Parmanto, B.; Zeng, X. Accessibility of Internet websites through time. In Proceedings of the 6th International ACM SIGACCESS Conference on Computers and Accessibility, Atlanta, GA, USA, 18-20 October 2004

18. Myhill, W.N.; Blanck, P. Law \& Policy Challenges for Achieving an Accessible Information Society in the EU: Lessons from America. Presented at the 2009 Mid-term Conference of the Nordic Centre of Excellence in Welfare Research (NCoE) 'Reassessing the Nordic Welfare Model', Oslo, Norway, 18-20 May 2009; Available online: http://www.nova.no/asset/3721/1/3721_1.pdf (accessed on 30 April 2018).

19. Blanck, P. Flattening the (inaccessible) cyberworld for people with disabilities. Assist. Technol. 2008, 20, 175-180. [CrossRef] [PubMed]

20. Krach, S.K.; Jelenic, M. The other technological divide: K-12 Web accessibility. J. Spec. Educ. Technol. 2009, 24, 31-37. [CrossRef]

21. Cantabrana, J.L.L.; Meritxell, E.M.; Tedesco, J.C. Inclusion and Social Cohesion in a Digital Society. Int. J. Educ. Technol. Higher Educ. 2015, 12, 44-58. [CrossRef]

22. Skjerve, R.; Giannoumis, G.A.; Naseem, S. An Intersectional Perspective on Web Accessibility. In Designing around People; Langdon, P., Lazar, J., Heylighen, A., Dong, H., Eds.; Springer: Cham, Switzerland, 2016; pp. 13-22. ISBN 978-3-319-29496-4.

23. Giannoumis, G.A.; Halvorsen, R. How do social institutions influence E-Accessibility polices in the UK, US, and Norway? Presented at the 8th International Conference on Evaluation for Practice: Improvement by Evaluation, Pori, Finland, 18-20 June 2012.

24. Foggetti, N. Special Briefing-e-Accessibility Standards Definition in the UN Convention on the Rights of Persons with Disabilities: Current Issues and Future Perspectives. Comput. Telecommun. Law Rev. 2012, 18, $56-61$.

25. United Nations Committee on the Rights of Persons with Disabilities. Communication No. 21/2014, F. v Austria, Views Adopted by the Committee at its Fourteenth Session, 17 August-4 September 2015, CRPD/C/14/D/21/2014, 2015. Available online: http://archiv.bka.gv.at/DocView.axd?CobId=61651 (accessed on 30 April 2018).

26. Ferri, D. The conclusion of the UN Convention on the rights of persons with disabilities by the EC/EU: A constitutional perspective. Eur. Yearb. Disabil. Law 2009, 1, 47-71.

27. Waddington, L. Breaking New Ground: The Implications of Ratification of the UN Convention on the Rights of Persons with Disabilities for the European Community. In The UN Convention on the Rights of Persons with Disabilities: European and Scandinavian Perspectives; Arnardottir, O.M., Quinn, G., Eds.; Martinus Nijhoff Publishers: Leiden, The Netherlands, 2009; pp. 111-140. ISBN 978-90-04-18080-2.

28. Watkins, D.; Burton, M. Research Methods in Law; Routledge: London, UK, 2017; ISBN 9781315386652.

29. Adam, A.; Kreps, D. Disability and Discourses of Web Accessibility. Inf. Commun. Soc. 2009, 12, $1041-1058$. [CrossRef]

30. Adam, A.; Kreps, D. Enabling or disabling technologies? A critical approach to Web accessibility. Inf. Technol. People 2006, 19, 203-218. [CrossRef]

31. Lazar, J.; Stein, M.A. (Eds.) Disability, Human Rights, and Information Technology; University of Pennsylvania Press: Philadelphia, PA, USA, 2017; ISBN 9780812249231.

32. Communication from the Commission to the European Parliament, the Council, the European Economic and Social Committee and the Committee of the Regions. European Disability Strategy 2010-2020: A Renewed Commitment to a Barrier-Free Europe. Brussels, 15 November 2010. COM(2010) 636 final. Available online: http:/ / eur-lex.europa.eu/LexUriServ /LexUriServ.do?uri=COM:2010:0636:FIN:en:PDF (accessed on 30 April 2018).

33. Communication from the Commission to the European Parliament. A Digital Agenda for Europe. Brussels, 19 May 2010. COM(2010) 245 final/2. Available online: https:/ / eur-lex.europa.eu/legal-content/EN/TXT/ ?uri=CELEX:52010DC0245 (accessed on 30 April 2018). 
34. Directive (EU) 2016/2102 of the European Parliament and of the Council of 26 October 2016 on the Accessibility of the Websites and Mobile Applications of Public Sector Bodies. OJ L 327, 2 December 2016. pp. 1-15. Available online: https:/ / eur-lex.europa.eu/legal-content/EN/TXT/?uri=CELEX\%3A32016L2102 (accessed on 30 April 2018).

35. European Commission. Proposal for a Directive of the European Parliament and of the Council on the Approximation of the Laws, Regulations and Administrative Provisions of the Member States as Regards the Accessibility Requirements for Products and Services. Brussels, 2 December 2015. COM (2015) 615 fin. 2015. Available online: https:/ / eur-lex.europa.eu/legal-content/EN/TXT/?uri=celex:52015PC0615 (accessed on 30 April 2018).

36. Peters, B. Web accessibility: An introduction and ethical implications. J. Inf. Commun. Ethics Soc. 2010, 8, 206-232. [CrossRef]

37. Harper, S.; Chen, A.Q. Web accessibility guidelines. A lesson from the evolving Web. World Wide Web 2012, 15, 61-88. [CrossRef]

38. Giannoumis, G.A. Auditing Web Accessibility: The Role of Interest Organizations in Promoting Compliance through Certification. First Monday 2015, 20. Available online: http:/ / firstmonday.org/ojs/index.php/fm/ article/view/6167/4901 (accessed on 30 April 2018). [CrossRef]

39. Brunsson, N.; Rasche, A.; Seidl, D. The dynamics of standardization: Three perspectives on standards in organization studies. Organ. Stud. 2012, 33, 613-632. [CrossRef]

40. Easton, C. The web content accessibility guidelines 2.0: An analysis of industry self-regulation. Int. J. Law Inf. Technol. 2011, 19, 74-93. [CrossRef]

41. W3C: HTML and XHTML Frequently Answered Questions. Available online: http:/ /www.w3.org/MarkUp/ 2004/xhtml-faq (accessed on 30 April 2018).

42. W3C: Briefing Package for Project Web Accessibility Initiative (WAI). Available online: http:/ /www.w3.org/ WAI/References/access-brief (accessed on 30 April 2018).

43. Kennedy, H.; Evans, S.; Thomas, S. Can the Web be made accessible for People with Intellectual Disabilities? Inf. Soc. 2011, 27, 29-39. [CrossRef]

44. Web Content Accessibility Guidelines (WCAG) 2.0. W3C Recommendation 11 December 2008. Available online: https:/ / www.w3.org/TR/WCAG20/ (accessed on 30 April 2018).

45. Understanding Conformance/Understanding WCAG 2.0. Available online: https://www.w3.org/TR/ UNDERSTANDING-WCAG20/conformance.html (accessed on 15 May 2018).

46. Duchateau, S.; Boulay, D.; Burger, D. Assessing WCAG 2.0 conformance in practice. In Computers Helping People with Special Needs. ICCHP 2010. Lecture Notes in Computer Science; Miesenberger, K., Klaus, J., Zagler, W., Karshmer, A., Eds.; Springer: Berlin/Heidelberg, Germany, 2010; Volume 6179, pp. 408-412. ISBN 9783642140969.

47. Brown, J.; Hollier, S. The Challenges of Web Accessibility: The Technical and Social Aspects of a Truly Universal Web. First Monday. 2015. Available online: https://journals.uic.edu/ojs/index.php/fm/article/ view /6165/4899\#p4 (accessed on 30 April 2018).

48. Abuaddous, H.Y.; Zalisham Jali, M.; Basir, N. Web Accessibility Challenges. IJACSA 2016, 7, $172-181$. [CrossRef]

49. Clark, J. To Hell with WCAG2. Accessibility. 2008. No. 217. Available online: http://alistapart.com/articles/ tohellwithwcag2 (accessed on 30 April 2018).

50. Power, C.; Pimenta Freire, A.; Petrie, H.; Swallow, D. Guidelines are Only Half of the Story: Accessibility Problems Encountered by Blind Users on the Web. In Proceedings of the SIGCHI Conference on Human Factors in Computing Systems, Austin, TX, USA, 5-10 May 2012.

51. Flash Eurobarometer 345: Accessibility. Available online: https:/ /data.europa.eu/euodp/data/dataset/ S1015_345 (accessed on 30 April 2018).

52. Public Consultation on the Review of the European Disability Strategy 2010-2020. Available online: http:// ec.europa.eu / social $/$ main.jsp?catId=699\&langId=en\&consultId=19\&visib=0\&furtherConsult=yes (accessed on 30 April 2018).

53. Kuzma, J.; Yen, D.; Oestreicher, K. Global e-government Web Accessibility: An Empirical Examination of EU, Asian and African Sites. Presented at the Second International Conference on Information and Communication Technologies and Accessibility, Hammamet, Tunisia, 7-9 May 2009. 
54. Scholz, F.; Yalcin, B.; Priestley, M. Internet access for disabled people: Understanding socio-relational factors in Europe. Cyberpsychology 2017, 11. [CrossRef]

55. Special Eurobarometer 393: Discrimination in the EU in 2012. Available online: https: / / www.europeandataportal.eu/data/en/dataset/http-ec-europa-eu-public_opinion-archives-eb_ special_399_380_en-htm393 (accessed on 30 April 2018).

56. Disability Rights Commission. The Web: Access and Inclusion for Disabled People. A Formal Investigation Conducted by the Disability Rights Commission. 2004. Available online: https:/ / www.city.ac.uk/_data/ assets/pdf_file/0004/72670/DRC_Report.pdf (accessed on 30 April 2018).

57. Priestley, M. The political participation of disabled people in Europe: Rights, accessibility and activism. Elect. Stud. 2016, 42, 1-9. [CrossRef]

58. Kuzma, J.M. Regulatory compliance and Web accessibility of U.K. Parliament sites. J. Inf. Law Technol. 2009, 2,1-15.

59. Kopackova, H.; Michalek, K.; Cejna, K. Accessibility and findability of local e-government Web sites in the Czech Republic. Univers. Access Inf. Soc. 2010, 9, 51-61. [CrossRef]

60. Paris, M. Web site accessibility: A survey of local e-government Web sites and legislation in Northern Ireland. Univers. Access Inf. Soc. 2006, 4, 292-299. [CrossRef]

61. Roig-Vila, R.; Ferrández, S.; Ferri-Miralles, I. Assessment of Web content accessibility levels in Spanish official online education environments. Int. Educ. Stud. 2014, 7, 31-45. [CrossRef]

62. Barricelli, B.R.; Sciarelli, P.; Valtolina, S.; Rizzi, A. Web accessibility legislation in Italy: A survey 10 years after the Stanca Act. Univers. Access Inf. Soc. 2018, 17, 211-222. [CrossRef]

63. Gambino, O.; Pirrone, R.; Di Giorgio, F. Accessibility of the Italian institutional web pages: A survey on the compliance of the Italian public administration web pages to the Stanca Act and its 22 technical requirements for web accessibility. Univers. Access Inf. Soc. 2016, 15, 305-312. [CrossRef]

64. National Disability Authority. Measures to Improve Accessibility of Public Websites in Europe. Ireland, 2014. Available online: http:/ / universaldesign.ie/Web-Content-/Measures-to-Improve-Accessibility-of-PublicWebsites-in-Europe-Exec-Summary.pdf (accessed on 30 April 2018).

65. Chiadò Piat, S.; Gianino, M.M.; Icardi, G.; Specchia, M.L.; Renga, G.; Siliquini, R. Visibility, accessibility and quality of Italian public health institutional websites. Ital. J. Public Health 2010, 7, 102-108. [CrossRef]

66. Mancini, C.; Zedda, M.; Barbaro, A. Health information in Italian public health websites: Moving from inaccessibility to accessibility. Health Inf. Lib. J. 2005, 22, 276-285. [CrossRef] [PubMed]

67. Committee on Employment and Social Affairs. Rapporteur Helga Stevens. Report on Implementation of the European Disability Strategy. Available online: http://www.europarl.europa.eu/sides/getDoc.do? pubRef=- / /EP / /TEXT+REPORT+A8-2017-0339+0+DOC+XML+V0 / /EN\#_part1_def13 (accessed on 30 April 2018).

68. Schmutz, S.; Sonderegger, A.; Sauer, J. Implementing recommendations from Web Accessibility Guidelines: Would they also provide benefits to nondisabled users. Hum. Factors 2016, 58, 611-629. [CrossRef] [PubMed]

69. Gonçalves, R.; Martins, J.; Pereira, J.; Au-Yong Oliveira, M.; Pinto Ferreira, J.J. Accessibility levels of Portuguese enterprise websites: Equal opportunities for all? Behav. Inf. Technol. 2011, 31, 659-677. [CrossRef]

70. The Click-Away Pound Survey. Available online: http://www.clickawaypound.com/ (accessed on 30 April 2018).

71. Lorca, P.; de Andrés, J.; Martínez, A.B. Does Web accessibility differ among banks? World Wide Web 2016, 19, 351-373. [CrossRef]

72. United Nations Committee on the Rights of Persons with Disabilities. General Comment No. 2 (2014); Adopted by the Committee at its eleventh session 31 March-11 April 2014, CRPD/C/GC/2; United Nations Committee on the Rights of Persons with Disabilities: New York, NY, USA, 2014.

73. Lord, J.E. Accessibility and Human Rights Fusion in the CRPD: Assessing the Scope and Content of the Accessibility Principle and Duty under the CRPD; United Nations Committee on the Rights of Persons with Disabilities: Geneva, Switzerland, 2010.

74. Della Fina, V.; Cera, R.; Palmisano, G. The United Nations Convention on the Rights of Persons with Disabilities: A Commentary; Springer: Berlin, Germany, 2017; ISBN 978-3-319-43790-3.

75. United Nations Committee on the Rights of Persons with Disabilities. General Comment No. 6 (2018) on Equality and Nondiscrimination; 26 April 2018, CRPD/C/GC/6; United Nations Committee on the Rights of Persons with Disabilities: New York, NY, USA, 2018. 
76. United Nations Committee on the Rights of Persons with Disabilities. General Comment No. 5 (2017) on Living Independently and Being Included in the Community; 27 October 2017, CRPD/C/GC/5; United Nations Committee on the Rights of Persons with Disabilities: New York, NY, USA, 2017.

77. Huffaker, R. Enforcing eAccessibility: Is the current legal framework adequate? Int. Rev. Law Comput. Technol. 2015, 29, 207-225. [CrossRef]

78. Lawson, A.M. Reasonable Accommodation and Accessibility Obligations: Towards a More Unified European Approach? Eur. Anti-Discrim. Law Rev. 2011, 11, 11-21.

79. EUROPE 2020. A Strategy for Smart, Sustainable and Inclusive Growth. COM/2010/2020 Final. Available online: https:/ / eur-lex.europa.eu/legal-content/EN/TXT/?uri=celex\%3A52010DC2020 (accessed on 30 April 2018).

80. Communication from the Commission to the European Parliament, the Council, the European Economic and Social Committee and the Committee of the Regions. A Digital Single Market Strategy for Europe. COM/2015/0192 Final. Available online: https:/ / eur-lex.europa.eu/legal-content/EN/TXT/?uri=celex\% 3A52015DC0192 (accessed on 30 April 2018).

81. European Parliament. Briefing Implementation in Action. The European Disability Strategy 2010-2020. July 2017. Available online: http:/ /www.europarl.europa.eu/RegData/etudes/BRIE/2017/603252/EPRS_BRI\% 282017\%29603252_EN.pdf (accessed on 30 April 2018).

82. Resolution of the Council of the European Union and the Representatives of the Governments of the Member States, Meeting within the Council, on a New European Disability Framework (2010/C 316/01). Available online: http:/ / eur-lex.europa.eu/legal-content/EN/TXT/PDF/?uri=CELEX:42010X1120(02) \&from=EN (accessed on 30 April 2018).

83. Hosking, D. Staying the course: The European disability strategy 2010-2020. Eur. Yearb. Disabil. Law 2013, 4, 73-97.

84. Mandate 376. Accessibility Requirements Suitable for Public Procurement of ICT Products and Services in Europe. Available online: http:/ / mandate376.standards.eu/standard (accessed on 30 April 2018).

85. Hosking, D. Promoting accessibility for disabled people using EU standardisation policy. Eur. Law Rev. 2017, 42, 145-165.

86. United Nations Committee on the Rights of Persons with Disabilities. Concluding Observations on the Initial Report of the European Union. 2 October 2015. CRPD/C/EU/CO/1. Available online: https:/ / documentsdds-ny.un.org/doc/UNDOC/GEN/G15/226/55/PDF/G1522655.pdf?OpenElement (accessed on 30 April 2018).

87. Ciolan, I.M. Advancing Europeanization through digital agenda: Effects on the social policy of EU. Revista De Administratie Publica Si Politici Sociale 2013, 11, 78-96.

88. Mansell, R. Here Comes the Revolution-The European Digital Agenda. In The Palgrave Handbook of European Media Policy; Donders, K., Pauwels, C., Loisen, J., Eds.; Palgrave Macmillan: London, UK, 2013; pp. $202-217$. ISBN 978-1-349-44102-0.

89. Gesetz vom 8. November 2017, mit dem das Tiroler Antidiskriminierungsgesetz 2005 geändert wird. Available online: https:/ / eur-lex.europa.eu/legal-content/EN/ALL/?uri=NIM\%3A254293 (accessed on 30 April 2018).

90. Proyecto de Real Decreto para la transposición de la Directiva (UE) 2016/2102. Available online: http:/ / www.minhafp.gob.es/Documentacion/Publico/NormativaDoctrina/Proyectos/Cuestionario\% 20consulta\%20previa\%20Transposici\%C3\%B3n\%20DAW\%20RD\%20v1_0.pdf (accessed on 30 April 2018).

91. EDF Toolkit on the Web Accessibility Directive. Available online: http://www.edf-feph.org/newsroom/ news/edf-toolkit-web-accessibility-directive (accessed on 30 April 2018).

92. E. T. S. Institute. EN 301549 V1.1.2 (2015-04)—Accessibility Requirements Suitable for Public Procurement. 2015. Available online: http://www.etsi.org/deliver/etsi_en/301500_301599/301549/01.01.02_60/en_ 301549v010102p.pdf (accessed on 30 April 2018).

93. Statement by Vice-President Ansip and Commissioner Oettinger Welcoming the Adoption of the first EU-Wide Rules to Make Public Sector Websites and Apps More Accessible, 26 October 2016. Available online: http:/ / europa.eu/rapid/press-release_STATEMENT-16-3549_en.htm (accessed on 30 April 2018).

94. Strategic Inquiry OI/6/2017/EA: Accessibility for Persons with Disabilities of Websites and Online Tools Managed by the European Commission, 12 July 2017. Available online: https: / www.ombudsman.europa. $\mathrm{eu} /$ it/cases/correspondence.faces/it/81349/html.bookmark (accessed on 30 April 2018). 
95. Comments of the Commission on a Strategic Inquiry from the European Ombudsman—ref. OI/6/2017/EA. Available online: https:/ / www.ombudsman.europa.eu/it/cases/correspondence.faces/en/84551/html. bookmark (accessed on 15 May 2018).

96. Easton, C. Website accessibility and the European Union: Citizenship, procurement and the proposed Accessibility Act. Int. Rev. Law Comput. Technol. 2013, 27, 187-199. [CrossRef]

97. Opinion of the European Economic and Social Committee on the Proposal for a Directive of the European Parliament and of the Council on the Approximation of the Laws, Regulations and Administrative Provisions of the Member States as Regards the Accessibility Requirements for Products and Services. COM(2015) 615 Final-2015/0278 (COD). OJ C 303. 19 August 2016, pp. 103-108. Available online: https:/ / eur-lex.europa. eu/legal-content/EN/TXT/?uri=celex:52016AE0050 (accessed on 30 April 2018).

98. EDF, The European Accessibility Act: State of Play 2014. Available online: http://www.edf-feph.org/ european-accessibility-act-1 (accessed on 30 April 2018).

99. Inclusion Europe's Position about the Proposed European Accessibility Act, 25 January 2016. Available online: http:/ / webcache.googleusercontent.com/search?q=cache:EAYYy8mTaNoJ:www.edf-feph. org/sites/default/files/inclusioneurope_eaa.pdf+\&cd=1\&hl=it\&ct=clnk\&gl=it (accessed on 15 May 2018).

100. European Parliament. Amendments Adopted by the European Parliament on 14 September 2017 on the Proposal for a Directive of the European Parliament and of the Council on the Approximation of the Laws, Regulations and Administrative Provisions of the Member States as Regards the Accessibility Requirements for Products and Services. COM(2015)0615-C8-0387/2015-2015/0278(COD). Available online: http:/ / www.europarl.europa.eu/sides/getDoc.do?pubRef=- / EP/ /TEXT+TA+P8-TA2017-0347+0+DOC+XML+V0/ / EN (accessed on 30 April 2018).

101. EDF. Accessibility Act: The Council of the EU Adopts Its Position. Available online: http://www.edf-feph. $\mathrm{org} /$ newsroom/news/accessibility-act-council-eu-adopts-its-position (accessed on 30 April 2018).

102. 2018/0001(NTT)-Joint Declaration 2018. Available online: http:/ /www.europarl.europa.eu/oeil/popups / thematicnote.do?id=2063000\&l=en (accessed on 30 April 2018).

103. 2017 Website Accessibility Lawsuit Recap: A Tough Year for Businesses. Available online: https://www. adatitleiii.com/2018/01/2017-website-accessibility-lawsuit-recap-a-tough-year-for-businesses / (accessed on 15 May 2018).

(C) 2018 by the authors. Licensee MDPI, Basel, Switzerland. This article is an open access article distributed under the terms and conditions of the Creative Commons Attribution (CC BY) license (http:/ / creativecommons.org/licenses/by/4.0/). 